\title{
INNOVATIONS AS A PRIORITY FACTOR OF THE REGIONAL ECONOMIC DEVELOPMENT
}

\author{
Lesia Dmytryshyn ${ }^{1}$ \\ Olena Zvarych ${ }^{2}$ \\ King Danylo University, Ukraine
}

Vasyl Stefanyk Precarpathian National University, Ukraine

\begin{abstract}
The goal of the paper is to study the role and assess the innovation impact on the economic development of the region. Methodology. Theoretical and methodological foundations of the research draw the works of scientists on the problems of economic development of regions. In the process of scientific research, a complex of such methods was used: content analysis, generalization, systematization - in order to specify the conceptual-categorical apparatus and identify features of innovation; dynamic, statistical, comparative analysis - when identifying the innovation influence features on the economic development of the region, mathematical modelling in economics - to develop a methodology for assessing the innovation impact on the economic development of the region. Results. Features of an innovative approach to the economic development of regions in the context of obtaining sustainable competitive advantage and strengthening of positions of regions on the international arena. The analysis of the innovativeness level of the regions' development was carried out and the methodical approach for determining the degree of innovation effectiveness in a hierarchical regional section was proposed, which is based on the use of tools of the multidimensional statistical analysis. At the same time, the effectiveness of regional innovation involves the implementation of these stages: formation of the statistical data matrix on the basis of the regional innovation factors by types of INPUT and OUTPUT, defying the degree of innovation of each region, determining the innovation effectiveness measure in the hierarchical regional context. It is established that the semantic interpretation of the regional innovation effectiveness requires clarification of the classification procedure of regions taking into account the chosen methodology for the correlation of INPUT and OUTPUT indices. It is substantiated that the innovation efficiency definition should take into account interregional differentiation, as a result of which the measure of the effectiveness of regional innovation, which takes into account: the ties between the country and regions forming a hierarchical structure, the connections between the innovation index of the region of INPUT type, and the innovation index of the region of OUTPUT type. Practical importance. It is established that the use of a single combined indicator and the rating table does not allow you to track the complexity of the innovation process itself, with innovation indicators shifting in favour of those countries specializing in high-tech industries, in particular, in high-tech manufacturing. The significance of the influence on innovation, in addition to financial, economic, and educational factors is substantiated, as well as technological, organizational and managerial, and especially social and psychological factors. On the basis of calculating the innovation efficiency of regions for the different values of the given index, it is established that its magnitude affects the place of the region in the classification of regions taking into account the chosen methodology of the correlation of INPUT and OUTPUT indices. In determining the degree of innovation effectiveness in the national context, it is proposed to use the regional innovation multiplier. Its value directly determines the position of the country with regard to the effectiveness of the use of innovations in a regional context and, therefore, can serve as a benchmark for national policy in this aspect. Importance/originality. On the basis of the conducted research, a methodical approach is proposed to evaluate the effectiveness of regional innovation on fundamentally new principles, which add an opportunity to reproduce the innovative potential and increase the technological and the information level of all spheres of economic activity of the region, to achieve a high level of competitiveness of its activity.
\end{abstract}

Key words: region, economic development, innovations, innovation index, regional innovation effectiveness.

JEL Classification: R10, O10, O30

Corresponding author:

${ }^{1}$ Department of Economic Cybernetics, Vasyl Stefanyk Precarpathian National University.

E-mail: dmytryshyn 1@hotmail.com

${ }^{2}$ Department of Tourism and Hotel and Restaurant Business, King Danylo University.

E-mail: lena_zl@ukr.net 


\section{Introduction}

Innovation is one of the determining factors in the competitiveness of the regions. The modern role of the economic region in the global economy is determined by the localization in its space of innovation and creative activity. The region, aimed at introducing innovations, undergoes continuous transformations, creates highly technological products, timely adjusts its strategic goals, which leads to stagnation.

An innovative approach to the economic regions' development contributes to the efficient use of the potential and resources of these spatial units, as a result of obtaining a sustainable competitive advantage and changing the place of economic regions on the international arena.

In the regional innovation system, different types of institutions have, to varying degrees, implemented the functions of production, circulation, and absorption (Lundval, 1992). Absorption of knowledge is basically enterprises, for the production of knowledge corresponds to universities and research institutions, both private and governmental. The circulation of knowledge is due to such factors as the regional innovation system, the business context institutions, regional authorities, innovation financing institutions, as well as research organizations and universities.

Given the role that innovation processes play in today's economy, identifying and taking into account their peculiarities is a necessary condition for ensuring the economic development of the regions and the state as a whole (Dolishnii, 2006). The concept of "innovation" is interpreted as the transformation of potential scientific and technological progress into an actual, resulting in new products, technologies, methods of production (Peresada, 2002).

In spite of numerous developments, it should be noted the need for further development of scientific-methodological principles and practical recommendations for the analysis and assessment of innovation in the economic development of the regions, especially in the context of prospects for the development of interregional integration processes (Storonianska, 2009).

In connection with the foregoing, the goal of the research is to study the role and assessment of the innovation impact on the economic development of the region.

\section{Research results}

Further, to determine the level of innovation of the regions of Ukraine, it is proposed to use, on the one hand, the structural dimension of development as an instrument of multidimensional statistical analysis, and on the other hand, indicators of the European Innovation Scoreboard (EIS) 2017 ("Methodology Report”, 2017). Based on this approach, it is proposed to determine the effectiveness of regional innovation in the next sequence:

- to form the matrix of statistical data on the basis of regional innovation factors separately by INPUT and OUTPUT types;

- to determine the innovation measure in each region; - to determine the innovation effectiveness measure in a hierarchical regional context.

Determination of matrices of statistical data. The European Innovation Scoreboard defines four distinct areas for identifying regional innovation:

1) knowledge creation and entrepreneurship;

2) investments;

3) innovative activity;

4) influences.

Allocated spaces can be grouped in the form of matrices by the following hierarchical or metric characteristics:

- in the national context,

- in terms of regions in each country,

- in the context of the meters of each group of INPUT,

- in the context of the meters of each group of OUTPUT.

According to indicator characteristics, indicators of regional innovation are grouped separately by INPUT and OUTPUT types and their respective national statistically calculated indicators and units of their measurement are selected (Table 1).

Construction of the regional innovation index. The next step is to build an innovation measure in the region type of INPUT and OUTPUT. The construction of the regional innovation index of the INPUT type relies on the partial indices defined for the two groups of meters:

- knowledge creation and entrepreneurship;

- investments.

The Partial Index of Regional Innovation Type of INPUT for each metric group using data for all regions in all countries is the arithmetic mean of the normalized values of each indicator for each region in each country. The normalized value is defined as the ratio of the deviation of the indicator from the minimum in the country to the deviation of the maximum and minimum values countrywide. Thus, we obtain a value, which changes range is from 0 to 1 .

The construction of the OUTPUT Regional Innovation Index relies on partial indexes for defined groups of metrics:

- innovative activity;

- influences.

The principle of calculating partial indices is the same as for INPUT indexes.

The constructed partial indices serve to construct regional innovation indices of INPUT and OUTPUT. These indices are, by analogy, the arithmetic mean of their partial indices. Therefore, their values will also vary in the interval $[0,1]$. Since all EIS indicators are stimulators, then the interpretation of the indices is as 
Table 1

Indicators of regional innovation by INPUT and OUTPUT types

\begin{tabular}{|c|c|}
\hline Indicators of regional innovation & Calculation methodology and measurement units \\
\hline \multicolumn{2}{|c|}{ Factors that represent regional innovation of INPUT type } \\
\hline \multicolumn{2}{|l|}{1 KNOWLEDGE CREATION AND ENTREPRENEURSHIP } \\
\hline \multicolumn{2}{|l|}{1.1 Human resources } \\
\hline 1.1.1 The number of postgraduate alumnus & Number of postgraduate alumnus per 1 thousand population, $\%$ \\
\hline \multicolumn{2}{|l|}{2 INVESTMENTS } \\
\hline \multicolumn{2}{|l|}{ 2.1 Finance and support } \\
\hline 2.1.1. R\&D W expenditure in the public sector & $\begin{array}{l}\text { The ratio of R\&D W expenditures in the public sector and the higher } \\
\text { education sector to the GRP, \% }\end{array}$ \\
\hline \multicolumn{2}{|l|}{2.2 Brand investments } \\
\hline 2.2.1 R\&D W expenses in business & Ratio of cost of R \& D W in business to GRP, $\%$ \\
\hline \multicolumn{2}{|c|}{ Factors that represent regional innovation of OUTPUT type } \\
\hline \multicolumn{2}{|l|}{3 INNOVATIVE ACTIVITY } \\
\hline \multicolumn{2}{|l|}{3.1 Innovators } \\
\hline 3.1.1 Industrial enterprises with new products or processes & $\begin{array}{l}\text { The ratio of the number of industrial enterprises to new products or } \\
\text { technological processes to the total number of industrial enterprises, } \\
\%\end{array}$ \\
\hline $\begin{array}{l}\text { 3.1.2 Industrial enterprises with marketing and organizational } \\
\text { innovations }\end{array}$ & $\begin{array}{l}\text { The ratio of the number of industrial enterprises that implemented } \\
\text { marketing and organizational innovations to the total number of } \\
\text { industrial enterprises, \% }\end{array}$ \\
\hline 3.1.3 Industrial enterprises with innovations in the company & $\begin{array}{l}\text { The ratio of the number of industrial enterprises that introduced new } \\
\text { products or processes both in their own production and in other } \\
\text { companies to a large number of industrial enterprises, } \%\end{array}$ \\
\hline \multicolumn{2}{|l|}{3.3 Intelligent assets } \\
\hline 3.3.1. Patent applications & The share of applications for inventions in GDP adjusted for CPI, \% \\
\hline 3.3.2 Trademark Orders & The share of patents in GDP adjusted for CPI, \% \\
\hline \multicolumn{2}{|l|}{4 INFLUENCES } \\
\hline \multicolumn{2}{|l|}{4.1 Influence on employment } \\
\hline 4.1.1 Employment in activities requiring knowledge & $\begin{array}{l}\text { The ratio of the number of employees involved in the } \\
\text { implementation of research and development to the GDP adjusted } \\
\text { for CPI, \% }\end{array}$ \\
\hline
\end{tabular}

follows: the closer to 1 index value shows the higher innovation INPUT or OUTPUT type. Both indices also enable the regions to be organized according to their level of regional innovation at the national level, taking into account the costs of innovation and the effects of innovation.

An important criterion for assessing regional innovation is its effectiveness. The basis for assessing the innovation efficiency of the region is the size of the INPUT and OUTPUT type indexes. Such an approach will allow the allocation of the regional spaces of the following classes:

Class I includes regions, for which the value of the INPUT index is higher than the value of the OUTPUT:

$$
\frac{I N P U T}{\text { OUTPUT }}>1+\alpha \text {, }
$$

where $\alpha$ - the value, given a priori.

Class II includes regions, for which the value of the indices INPUT and OUTPUT is equal:

$$
1-\alpha \leq \frac{I N P U T}{\text { OUTPUT }} \leq 1+\alpha .
$$

Class III includes regions, for which the value of the INPUT index is lower than the OUTPUT value:

\section{$\frac{I N P U T}{\text { OUTPUT }}<1-\alpha$.}

Introduction of the parameter $\alpha$ to determine the effectiveness of the region's innovation will allow individualizing the estimates through the perception of the researcher's assessment. The presented procedure of measuring regional innovation allows determining the extent, to which the innovation of the region is effective (Strahl, 2007):

$$
M_{k}^{n}=10^{c_{k}}, k=1, \ldots, K, n=1, \ldots, N,
$$

where $c=0,1,2 ; \quad M_{k}^{n}$ - a measure of the innovation efficiency of the region $p$, which belongs to the country $P$.

The effectiveness of the country's innovation. The measure of the effectiveness of the country's innovation $\mathrm{P}$ in the hierarchical region is determined by the formula (Strahl, 2007):

$$
M E I K_{k}^{n}=\frac{\sum_{k=1}^{K} M_{k}^{n}}{K \cdot 100},
$$

where $M E I K$ - a measure of the effectiveness of the country's innovation $P$; $M_{k}^{n}$ - the innovation efficiency 
measure in the region $p$, which belongs to the country $P ; K$ - the number of regions in the $n$-th country, $n=1,2, \ldots, N$.

It is easy to note that the value of the measure of innovation efficiency in the hierarchical regional section belongs to the numerical range $[0,01 ; 1]$. Measures closer to the minimum mean that the country has a weak position in terms of the innovations' effectiveness in a regional context, and closer to 1 values indicate the high efficiency of innovation in the country in a regional context.

The demonstrated approach to determining the measure of innovation efficiency in a hierarchical regional section is based on the use of instruments of multidimensional statistical analysis and the statistics data of the European Union or the State Statistics Service of Ukraine in the field of innovation.

Empirical results. The analysis of innovation was carried out on the example of indicators, shown in Table 1 for the regions of Ukraine for the period of 2010-2016.

On the basis of normalized values, matrices of indices of regional innovation are formed separately according to the INPUT and OUTPUT types (Table 2-3).
Since all EIS indicators are stimulators, the closer to 1 index value shows higher innovation INPUT type. As can be seen from Figure 1, for the period under the study, the highest level of innovation is inherent to Kyiv and Kharkiv region. All other regions have values lower than 0,25. Accordingly, it can be concluded that there is no regional and state policy to stimulate and support innovation, as the costs for them are too scanty, especially on a regional scale. All funds for innovation remain in the centre, thus stimulating the development of the economy of regions of Ukraine on the principle of "centre-periphery". Such centripetal model leads to decrease in the interest of domestic and, in particular, foreign investors in the regional innovation support, and, on the other hand, further concentrates innovation potential in the centre.

Regarding the results of the introduction of innovations, the leading positions are again occupied by Kharkiv region, Kyiv and Sevastopol cities (Figure 2). Somewhat higher values in comparison with the INPUT index are Zaporizhzhia, Sumy, Odesa, Ivano-Frankivsk, Mykolaiv, and Lviv regions. This suggests that innovation, besides financial-economic

Table 2

Indices of INPUT regional innovation, \%

\begin{tabular}{|c|c|c|c|c|c|c|}
\hline & 2010 & 2012 & 2013 & 2014 & 2015 & 2016 \\
\hline Ukraine & 0,22 & 0,22 & 0,22 & 0,24 & 0,14 & 0,17 \\
\hline $\begin{array}{l}\text { Autonomous Republic } \\
\text { of Crimea }\end{array}$ & 0,13 & 0,10 & 0,09 & $-^{*}$ & -* & $-^{*}$ \\
\hline Vinnytsia & 0,05 & 0,03 & 0,02 & 0,06 & 0,04 & 0,03 \\
\hline Volyn & 0,03 & 0,03 & 0,04 & 0,05 & 0,17 & 0,17 \\
\hline Dnipropetrovsk & 0,13 & 0,13 & 0,12 & 0,15 & 0,07 & 0,10 \\
\hline \begin{tabular}{|l|} 
Donetsk \\
\end{tabular} & 0,09 & 0,07 & 0,08 & 0,02 & 0,01 & 0,00 \\
\hline Zhytomyr & 0,02 & 0,02 & 0,02 & 0,04 & 0,03 & 0,02 \\
\hline Zakarpattia & 0,04 & 0,05 & 0,06 & 0,07 & 0,02 & 0,02 \\
\hline Zaporizhzhia & 0,21 & 0,22 & 0,18 & 0,21 & 0,18 & 0,28 \\
\hline Ivano-Frankivsk & 0,12 & 0,09 & 0,04 & 0,06 & 0,07 & 0,06 \\
\hline Kyiv & 0,12 & 0,10 & 0,09 & 0,10 & 0,01 & 0,03 \\
\hline Kirovohrad & 0,01 & 0,01 & 0,01 & 0,03 & 0,02 & 0,01 \\
\hline Luhansk & 0,05 & 0,06 & 0,05 & 0,04 & 0,13 & 0,10 \\
\hline Lviv & 0,29 & 0,22 & 0,24 & 0,26 & 0,14 & 0,12 \\
\hline Mykolaiv & 0,08 & 0,08 & 0,08 & 0,10 & 0,05 & 0,05 \\
\hline Odesa & 0,15 & 0,16 & 0,16 & 0,19 & 0,13 & 0,13 \\
\hline Poltava & 0,03 & 0,04 & 0,05 & 0,06 & 0,04 & 0,04 \\
\hline Rivne & 0,02 & 0,01 & 0,01 & 0,03 & 0,03 & 0,03 \\
\hline Sumy & 0,09 & 0,15 & 0,10 & 0,16 & 0,08 & 0,09 \\
\hline Ternopil & 0,04 & 0,04 & 0,04 & 0,04 & 0,36 & 0,36 \\
\hline Kharkiv & 0,69 & 0,70 & 0,72 & 0,76 & 0,45 & 0,45 \\
\hline Kherson & 0,07 & 0,06 & 0,06 & 0,08 & 0,02 & 0,02 \\
\hline Khmelnytskyi & 0,01 & 0,02 & 0,02 & 0,01 & 0,03 & 0,02 \\
\hline Cherkasy & 0,05 & 0,05 & 0,05 & 0,07 & 0,04 & 0,04 \\
\hline Chernivtsi & 0,11 & 0,07 & 0,07 & 0,10 & 0,05 & 0,04 \\
\hline Chernihiv & 0,03 & 0,03 & 0,02 & 0,05 & 0,02 & 0,01 \\
\hline Kyiv city & 0,79 & 0,77 & 0,76 & 0,76 & 0,49 & 0,61 \\
\hline Sevastopol city & 0,25 & 0,20 & 0,26 & $-^{*}$ & $-^{*}$ & $-^{*}$ \\
\hline
\end{tabular}

* - no data available. 
Table 3

Indices of OUTPUT regional innovation, \%

\begin{tabular}{|c|c|c|c|c|c|c|}
\hline & 2010 & 2012 & 2013 & 2014 & 2015 & 2016 \\
\hline Ukraine & 0,33 & 0,37 & 0,38 & 0,40 & 0,40 & 0,40 \\
\hline $\begin{array}{l}\text { Autonomous Republic } \\
\text { of Crimea }\end{array}$ & 0,13 & 0,10 & 0,12 & -* & $-^{*}$ & -* \\
\hline Vinnytsia & 0,20 & 0,26 & 0,37 & 0,29 & 0,25 & 0,25 \\
\hline Volyn & 0,08 & 0,16 & 0,14 & 0,10 & 0,11 & 0,16 \\
\hline Dnipropetrovsk & 0,23 & 0,24 & 0,27 & 0,28 & 0,23 & 0,35 \\
\hline Donetsk & 0,17 & 0,22 & 0,21 & 0,22 & 0,10 & 0,12 \\
\hline Zhytomyr & 0,15 & 0,33 & 0,33 & 0,15 & 0,26 & 0,23 \\
\hline Zakarpattia & 0,28 & 0,24 & 0,19 & 0,25 & 0,36 & 0,25 \\
\hline Zaporizhzhia & 0,31 & 0,47 & 0,50 & 0,46 & 0,46 & 0,47 \\
\hline Ivano-Frankivsk & 0,29 & 0,43 & 0,44 & 0,45 & 0,35 & 0,29 \\
\hline Kyiv & 0,15 & 0,15 & 0,22 & 0,21 & 0,25 & 0,24 \\
\hline Kirovohrad & 0,14 & 0,23 & 0,28 & 0,24 & 0,41 & 0,23 \\
\hline Luhansk & 0,11 & 0,18 & 0,18 & 0,21 & 0,22 & 0,10 \\
\hline Lviv & 0,31 & 0,29 & 0,32 & 0,40 & 0,45 & 0,43 \\
\hline Mykolaiv & 0,25 & 0,31 & 0,34 & 0,34 & 0,56 & 0,41 \\
\hline Odesa & 0,26 & 0,35 & 0,35 & 0,37 & 0,48 & 0,45 \\
\hline Poltava & 0,09 & 0,07 & 0,10 & 0,09 & 0,24 & 0,16 \\
\hline Rivne & 0,11 & 0,21 & 0,24 & 0,22 & 0,09 & 0,12 \\
\hline Sumy & 0,47 & 0,44 & 0,39 & 0,38 & 0,43 & 0,41 \\
\hline Ternopil & 0,21 & 0,39 & 0,22 & 0,27 & 0,34 & 0,49 \\
\hline Kharkiv & 0,67 & 0,81 & 0,85 & 0,94 & 0,94 & 0,94 \\
\hline Kherson & 0,21 & 0,28 & 0,32 & 0,29 & 0,36 & 0,27 \\
\hline Khmelnytskyi & 0,15 & 0,42 & 0,35 & 0,20 & 0,16 & 0,12 \\
\hline Cherkasy & 0,25 & 0,29 & 0,30 & 0,23 & 0,29 & 0,27 \\
\hline Chernivtsi & 0,24 & 0,24 & 0,21 & 0,21 & 0,41 & 0,38 \\
\hline Chernihiv & 0,14 & 0,25 & 0,26 & 0,16 & 0,16 & 0,20 \\
\hline Kyiv city & 0,75 & 0,73 & 0,72 & 0,69 & 0,57 & 0,60 \\
\hline Sevastopol city & 0,56 & 0,70 & 0,50 & $-_{-*}^{*}$ & $-*$ & $--^{*}$ \\
\hline
\end{tabular}

* - no data available.

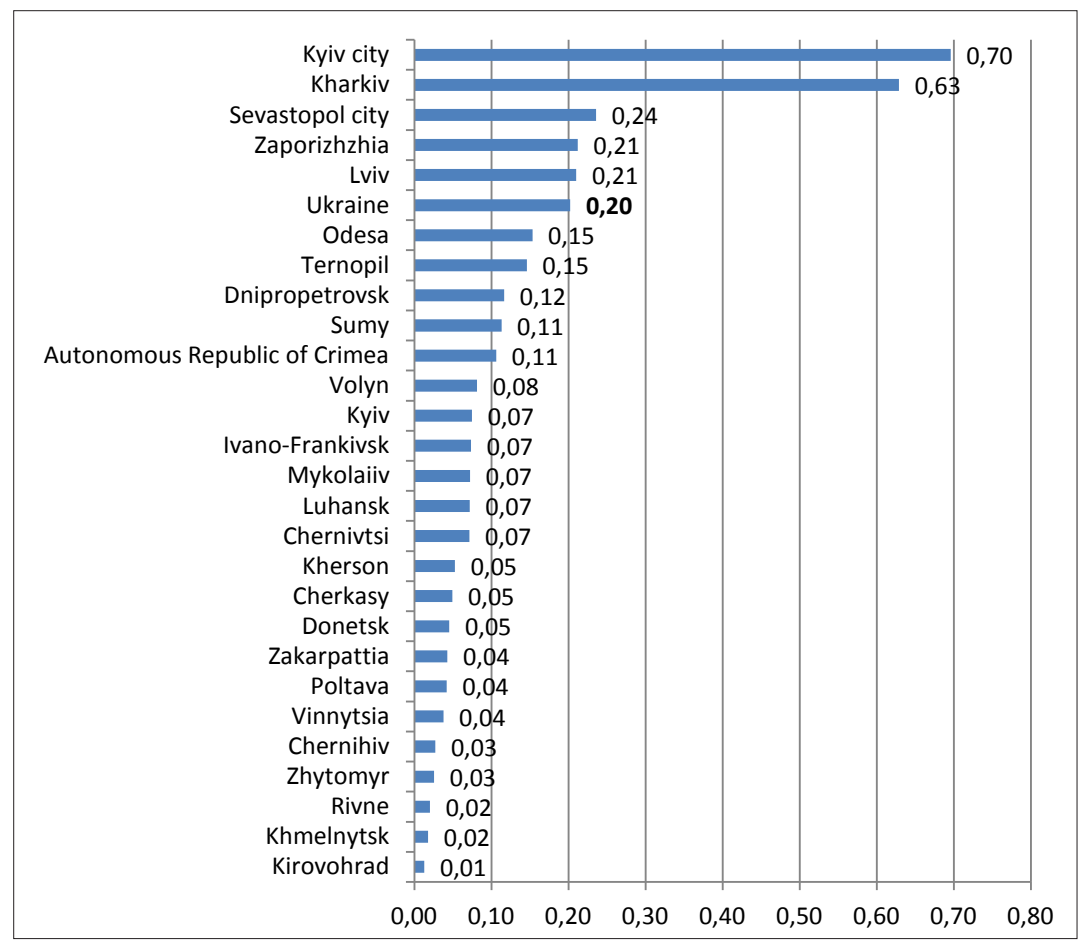

Figure 1. Average indices of innovation INPUT type for the period of 2010-2016 
Vol. 4, No. 2, 2018

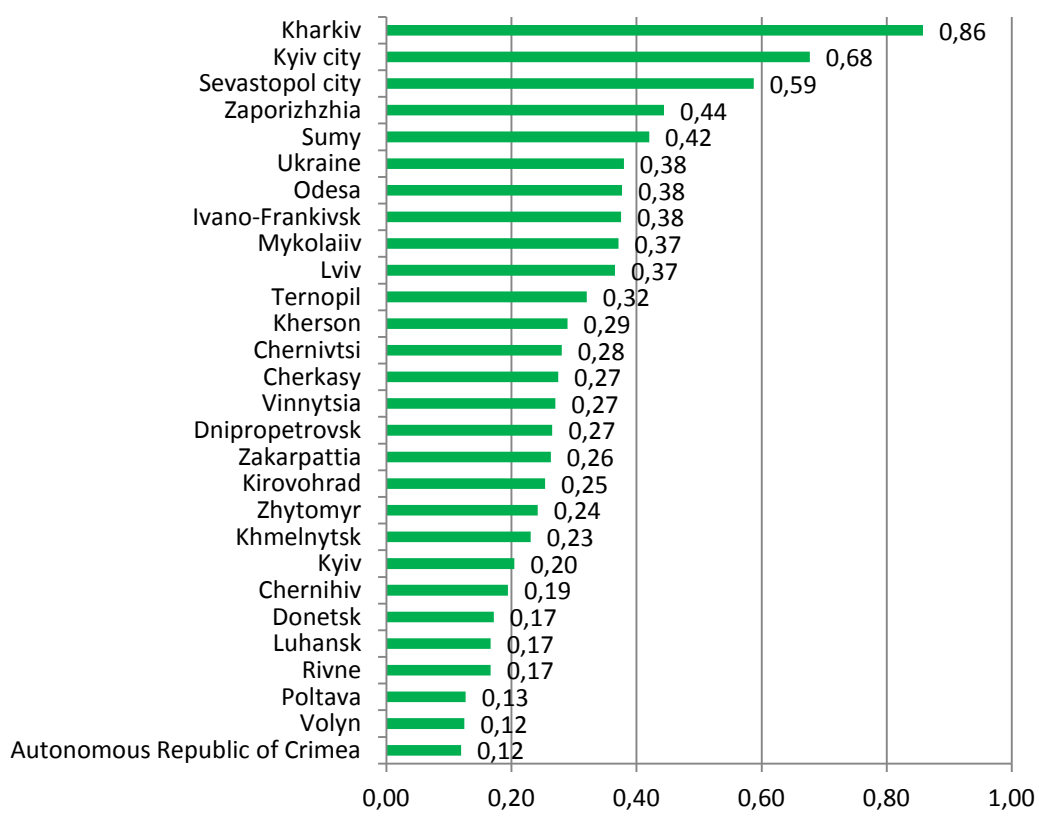

Figure 2. Average values of innovation indices OUTPUT type for the period of 2010-2016

and educational factors, has another impact, not reflected in the EIS. The effectiveness of innovations also depends on technological (orientation on the modern technologies development and market needs in new products), organizational and managerial (state of management, ability to innovate, change, restructuring, regional management structure) and, in particular, socio-psychological (attitudes, expectations and a reaction to the introduction of innovations) factors.

The next step is to assess the effectiveness of regional innovation, determined from the comparison of INPUT-type innovations to the OUTPUT-type innovation indices (Table 4).

Table 4

The innovation effectiveness evaluating of the regions of Ukraine

\begin{tabular}{|c|c|c|c|c|c|c|}
\hline & 2010 & 2012 & 2013 & 2014 & 2015 & 2016 \\
\hline 1 & 2 & 3 & 4 & 5 & 6 & 7 \\
\hline Ukraine & 0,68 & 0,58 & 0,57 & 0,60 & 0,35 & 0,44 \\
\hline $\begin{array}{l}\text { Autonomous Republic } \\
\text { of Crimea }\end{array}$ & 1,01 & 0,97 & 0,70 & -* $^{*}$ & $-^{*}$ & $-^{*}$ \\
\hline Vinnytsia & 0,24 & 0,10 & 0,07 & 0,19 & 0,15 & 0,14 \\
\hline Volyn & 0,31 & 0,18 & 0,28 & 0,52 & 1,64 & 1,05 \\
\hline Dnipropetrovsk & 0,57 & 0,54 & 0,45 & 0,54 & 0,29 & 0,30 \\
\hline \begin{tabular}{|l|} 
Donetsk \\
\end{tabular} & 0,55 & 0,35 & 0,39 & 0,07 & 0,07 & 0,01 \\
\hline Zhytomyr & 0,16 & 0,06 & 0,07 & 0,24 & 0,11 & 0,10 \\
\hline Zakarpattia & 0,15 & 0,19 & 0,29 & 0,28 & 0,07 & 0,08 \\
\hline Zaporizhzhia & 0,67 & 0,46 & 0,35 & 0,47 & 0,39 & 0,60 \\
\hline Ivano-Frankivsk & 0,41 & 0,21 & 0,10 & 0,13 & 0,21 & 0,20 \\
\hline Kyiv & 0,80 & 0,62 & 0,40 & 0,49 & 0,05 & 0,12 \\
\hline Kirovohrad & 0,05 & 0,04 & 0,02 & 0,11 & 0,04 & 0,06 \\
\hline Luhansk & 0,44 & 0,31 & 0,28 & 0,21 & 0,62 & 0,99 \\
\hline Lviv & 0,92 & 0,77 & 0,74 & 0,64 & 0,31 & 0,28 \\
\hline Mykolaiv & 0,31 & 0,25 & 0,24 & 0,30 & 0,08 & 0,12 \\
\hline Odesa & 0,59 & 0,45 & 0,44 & 0,53 & 0,27 & 0,28 \\
\hline Poltava & 0,32 & 0,52 & 0,49 & 0,64 & 0,15 & 0,25 \\
\hline Rivne & 0,17 & 0,05 & 0,06 & 0,12 & 0,28 & 0,22 \\
\hline Sumy & 0,20 & 0,35 & 0,26 & 0,41 & 0,20 & 0,22 \\
\hline Ternopil & 0,20 & 0,09 & 0,16 & 0,16 & 1,06 & 0,74 \\
\hline Kharkiv & 1,04 & 0,87 & 0,85 & 0,81 & 0,47 & 0,48 \\
\hline
\end{tabular}


End of Table 4

\begin{tabular}{|l|c|c|c|c|c|c|}
\hline \multicolumn{1}{|c|}{1} & 2 & 3 & 4 & 5 & 6 \\
\hline Kherson & 0,32 & 0,23 & 0,20 & 0,27 & 0,06 & 0,07 \\
\hline Khmelnytskyi & 0,06 & 0,04 & 0,05 & 0,07 & 0,17 \\
\hline Cherkasy & 0,20 & 0,15 & 0,16 & 0,29 & 0,15 \\
\hline Chernivtsi & 0,46 & 0,28 & 0,34 & 0,46 & 0,11 \\
\hline Chernihiv & 0,24 & 0,12 & 0,09 & 0,29 & 0,12 \\
\hline Kyiv city & 1,05 & 1,05 & 1,05 & 1,10 & 0,10 \\
\hline Sevastopol city & 0,44 & 0,28 & 0,53 & $-^{*}$ & 1,02 \\
\hline
\end{tabular}

* - no data available.

On the basis of assessments of regional innovation, the degree of innovation efficiency of Ukrainian regions is determined, which depends on the value $\alpha$.

Thus, when $\alpha=0,01$ we can select the following regional spaces:

- Kyiv City - belongs to Class I, in which costs for innovation exceed the obtained results throughout the period under study (the INPUT innovation index exceeds the value of the OUTPUT innovation indicator);

- Class II is an empty set;

- Vinnytsia, Dnipropetrovsk, Donetsk, Zhytomyr, Zakarpattia, Zaporizhzhia, Ivano-Frankivsk, Kyiv, Kirovohrad, Luhansk, Lviv, Mykolaiv, Odesa, Poltava, Rivne, Sumy, Kherson, Khmelnytskyi, Cherkasy, Chernivtsi, Chernihiv regions, the city of Sevastopol belong to class III, namely, the expenses for innovation are less than the obtained results (the value of the INPUT type index is lower than the value of the OUTPUT type index);

- all the rest of the region migrated from one class to another during the period under study.

In the case when $\alpha=0,8$, the regions were regrouped into classes:

- Class I is an empty set;

- Dnipropetrovsk, Zaporizhzhia, Luhansk, Lviv, Odesa, Kharkiv, Kyiv city, Sevastopol city, Autonomous Republic of Crimea - belong to Class II, namely the expenses for innovation and the obtained results are approximately the same in size;

- Kirovohrad, Khmelnytskyi regions - belong to Class III, namely, the expenses for innovation are less than the obtained results (the value of the INPUT type index is lower than the OUTPUT type index value);

- all the rest of the region migrated from one class to another during the period under study.

It is interesting, that when $\alpha=1$ all regions are in Class II. Thus, we can conclude that while approximating $\alpha$ to 0 or 1 regions are concentrated in one of the classes. If $\alpha$ is inside the range between 0 and 1 , then the regions are sprayed across different classes.

The proposed measure of innovation efficiency of the regions has allowed determining the effectiveness measure of the country's innovation (MEIC). Table 5 gives estimates of the MEIC for different values of $\alpha$.
Table 5

The evaluation of the effectiveness measures of innovation in the national context (MEIC)

\begin{tabular}{|l|c|c|c|c|c|c|}
\hline Parameter & 2010 & 2012 & 2013 & 2014 & 2015 & 2016 \\
\hline$\alpha=0,01$ & 0,89 & 0,96 & 0,96 & 0,96 & 0,92 & 0,92 \\
\hline$\alpha=0,2$ & 0,87 & 0,90 & 0,93 & 0,93 & 0,89 & 0,89 \\
\hline$\alpha=0,4$ & 0,80 & 0,83 & 0,87 & 0,86 & 0,85 & 0,82 \\
\hline$\alpha=0,6$ & 0,57 & 0,70 & 0,70 & 0,60 & 0,82 & 0,78 \\
\hline$\alpha=0,8$ & 0,30 & 0,43 & 0,43 & 0,35 & 0,60 & 0,53 \\
\hline$\alpha=1$ & 0,10 & 0,10 & 0,10 & 0,11 & 0,11 & 0,11 \\
\hline
\end{tabular}

As can be seen from Table 5, the significance of the measure of innovation efficiency in the national context belongs to the numerical range $[0,01 ; 1]$. Measures that are closer to the minimum mean that the country has a weak position in terms of the effectiveness of innovation in a regional context, and closer to 1 value indicate the high efficiency of innovation in the country in a regional context.

Increase in value $\alpha$ leads to a reduction in the assessment of the effectiveness of innovation in the national context. That is the indicator $\alpha$ can be interpreted as the regions innovativeness multiplier. Its value directly determines the position of the country with regard to the effectiveness of the use of innovation in a regional context and, therefore, can serve as a benchmark for national policy in this matter.

\section{Conclusions}

Thus, on the basis of the conducted analysis of the innovation assessment, a methodological approach is proposed for determining the degree of innovation efficiency in a hierarchical regional section based on the use of instruments of multidimensional statistical analysis. An analysis of the innovation of the regions of Ukraine based on the use of the proposed methodological approach made it possible to draw the following conclusions:

- the proposed EIS does not contain a basic innovation model that justifies the choice of innovation dimensions and indicators and reflects the reasons that innovation policy may affect;

- the use of a single combined indicator and rating table does not make it possible to control the complexity of the innovation process itself; 
- too many indicators determine innovations in hightech industries. It shifts the innovation indicators on behalf of those countries that specialize in high-tech industries, in particular, in high-quality production;

- many indicators are highly correlated, and these indicators can thus cover and measure the same aspect of the innovation process;

- many indicators for Ukrainian statistics are not available and, therefore, missing data can jeopardize the reliability and correctness of comparing the results of Ukraine's innovation activities with other countries;

- for the period under the study, a high level of innovation is inherent only in Kyiv and Kharkiv regions. All other regions have values lower than 0,25. Accordingly, it can be concluded that there is no regional and state policy to stimulate and support innovation, as the costs for them are too scanty, especially on a regional scale. All funds for innovation remain in the centre, thus, stimulating the development of the economy of the regions of Ukraine on the principle of "centreperiphery";

- according to the evaluation results of the innovations implementation, the leading positions occupy Kharkiv region, Kyiv and Sevastopol cities. Somewhat higher values compared to the INPUT index have Zaporizhzhia, Sumy, Odesa, Ivano-Frankivsk, Mykolaiv, and Lviv regions. This testifies to the fact that innovation, besides financial-economic and educational factors, has an impact, as well as other, in particular, technological, organizational-managerial and, especially, sociopsychological factors;

- when calculating the measure of the effectiveness of the innovation of the regions of Ukraine for various of them, it is established that this magnitude affects the place of the region in the classification of regions of Ukraine in view of the chosen method of the ratio of INPUT and OUTPUT indices. Moreover, when approaching $\alpha$ to 0 or 1 , the regions are concentrated in one of the classes. If $\alpha$ is inside the range between 0 and 1 , then the regions are sprayed across different classes; - in determining the measure of the effectiveness of innovation in the national context, it is suggested that the indicator $\alpha$ can be interpreted as the regions innovativeness multiplier. Its value directly determines the position of the country with regard to the effectiveness of the use of innovations in a regional context and, therefore, can serve as a benchmark for national policy in this aspect.

\section{References:}

Dolishnii, M.I. (2006) Rehionalna polityka na rubezhi XX-XXI stolit: novi priorytety. [Regional policy at the turn of XX-XXI centuries: new priorities]. Kyiv: Scientific thought, 512 [in Ukrainian].

Lundvall, B.A. (1992) National systems of innovation: towards a theory of innovation and interactive learning. London: Pinter Publishers, 342 [in English].

Methodology Report on European Innovation Scoreboard 2017. Retrieved from: http://ec.europa.eu/DocsRoom/ documents/25101 [in English].

Peresada, A.A. (2002). Upravlinnia Investytsiinym Protsesom [Investment process management] Kyiv: Libra, 472 [in Ukrainian].

Strahl D. (2007) Propozycja miary efektywności innowacyjności w hierar-chicznym przekroju regionalnym $\mathrm{z}$ wykorzystaniem European Innovation Scoreboard. Prace Naukowe Akademii Ekonomicznej we Wroctawiu. Ekonometria, 19, 9-18 [in Polish].

Storonianska, I.Z. (2009) Mizhrehionalni intehratsiini protsesy v Ukraini: tendentsii ta perspektyvy rozvytku [Interregional integration processes in Ukraine: trends and development prospects]. Lviv: Institute for Regional Studies of the National Academy of Sciences of Ukraine, 392 [in Ukrainian]. 